\title{
Synthesis and characterization of $\operatorname{LiMg}_{y} \mathrm{Mn}_{2-y} \mathrm{O}_{4}$ cathode materials by a modified Pechini process for lithium batteries
}

\author{
A SUBRAMANIA*, N ANGAYARKANNI, A R SATHIYA PRIYA, \\ R GANGADHARAN and T VASUDEVAN \\ Department of Industrial Chemistry, Alagappa University, Karaikudi 630 003, India
}

MS received 15 December 2004; revised 6 September 2005

\begin{abstract}
Cubic spinels of composition, $\mathrm{LiMg}_{y} \mathrm{Mn}_{2-y} \mathrm{O}_{4}$, with $y=0 \cdot 0,0 \cdot 05,0 \cdot 1,0 \cdot 15$ and $0 \cdot 2$, were synthesized by a modified Pechini process using polyethylene glycol and citric acid. The phase formation and/or crystallization of the precursors were studied by thermal analysis. Products were characterized by X-ray diffraction and SEM analysis. Coin cells were fabricated with lithium as the anode and $\mathrm{LiMg}_{y} \mathrm{Mn}_{2-y} \mathrm{O}_{4}$ as the cathode in an electrolyte of $1 \mathrm{M} \mathrm{LiPF}_{6}$ in a $1: 1$ (v/v) mixture of EC and DEC. The charge-discharge studies were performed and the results were compared with materials prepared by a solid state thermal method.
\end{abstract}

Keywords. Lithium batteries; cathode material; modified Pechini process; cubic spinel materials.

\section{Introduction}

Among the various insertion compounds used in lithium batteries, $\mathrm{LiMn}_{2} \mathrm{O}_{4}$ spinel is attractive as a positive electrode material due to its low cost and less toxic nature (Ozhuku et al 1990; Guyomard and Tarason 1994). However, $\mathrm{LiMn}_{2} \mathrm{O}_{4}$ suffers from capacity fade, which limits its cyclability. The capacity fading is due to John-Teller distortion effect (Gummow et al 1994) and lattice instability of pure spinel compounds at higher oxidation levels (Yamada 1996). But doped spinels have no such distortion effect. Hence capacity fading is independent of temperature. In order to overcome these problems, substitution of some of the manganese with additional lithium $\left(\mathrm{Li}_{1+x}\right.$ $\left.\mathrm{Mn}_{2-x} \mathrm{O}_{4}\right)$ or with several cations $\left(\mathrm{LiM}_{y} \mathrm{Mn}_{2-y} \mathrm{O}_{4}\right.$, where $\mathrm{M}=\mathrm{Ni}, \mathrm{Co}, \mathrm{Cr}$ and $\mathrm{Al}$ ) (Morita et al 2001; Lee et al 2004) has been widely explored. The electrochemical behaviour of these materials also depends upon the method of synthesis (Gummow et al 1994). In recent years, several low temperature techniques such as sol-gel (Hwang et al 2001), combustion (Kovacheva et al 2002), precipitation (Shaju et al 2002) and emulsion drying (Myung et al 2000) have also been used for the synthesis of $\mathrm{LiMn}_{2} \mathrm{O}_{4}$ spinels. Although these methods offer a greater degree of homogeneity, they require careful manipulation which may increase the cost of production and it may also require high temperature heating (above $800^{\circ} \mathrm{C}$ ) for $10-12 \mathrm{~h}$ to get the final product.

Very recently, Pechini process (U.S. Pat. 1967) has been used for the synthesis of $\mathrm{LiMn}_{2} \mathrm{O}_{4}$ because it eliminates some drawbacks inherent in the other low temperature

*Author for correspondence (a_subramania@ $@$ rediffmail.com) processes and also gives high purity products with controlled stoichiometries. Other low temperature processes are not always effective at maintaining a homogeneous reactant distribution during heating; the result is that undesirable phase can form at the beginning of calcinations (Bach et al 1990; Barboux et al 1991). But in Pechini process a $1: 4$ molar ratio of citric acid and ethylene glycol is used and several steps are involved to get the polymeric precursor. All these steps are tedious and care must be taken in every step including in the removal of any excess ethylene glycol by heating to about $180^{\circ} \mathrm{C}$ under reduced pressure. As ethylene glycol is eliminated, polyesterification occurs (Liu et al 1996). In order to eliminate the above drawbacks of the Pechini process, in the present investigation, a modified Pechini process is introduced in which both citric acid and PEG are directly used in the reaction process.

Hence in the present study, we have shown the possibility of synthesizing substituted $\mathrm{LiMn}_{2} \mathrm{O}_{4}$ by a modified Pechini process. The electrochemical behaviour of cathode materials during charging and discharging were also investigated. These results were compared with materials prepared by a solid-state thermal method.

\section{Experimental}

\subsection{Synthesis}

Nano-crystalline cubic spinel, $\mathrm{LiMg}_{y} \mathrm{Mn}_{2-y} \mathrm{O}_{4}(y=0 \cdot 10,0 \cdot 15$, $0.20,0.25)$ powders, were prepared by a modified Pechini process. AnalaR grade $\mathrm{LiNO}_{3}, \mathrm{Mg}\left(\mathrm{NO}_{3}\right)_{2}$ and $\mathrm{Mn}\left(\mathrm{CH}_{3} \mathrm{COO}\right)_{2}$ were used as the starting materials. In this method, stoichiometric amount of $\mathrm{LiNO}_{3}, \mathrm{Mg}\left(\mathrm{NO}_{3}\right)_{2}$ and 
$\mathrm{Mn}\left(\mathrm{CH}_{3} \mathrm{COO}\right)_{2}$ were taken and made into a homogeneous solution with distilled water. In the above solution, required quantity of citric acid and polyethylene glycol were added and then the solution was heated to $100^{\circ} \mathrm{C}$ to make it viscous. Interestingly polyethylene glycol acts as a dispersing agent as well as secondary fuel.

According to a concept developed in propellant chemistry (Jain et al 1981), the oxidizing valency (O) of $\mathrm{LiNO}_{3}$ was $-5, \operatorname{Mg}\left(\mathrm{NO}_{3}\right)_{2},-10$ and $\mathrm{Mn}\left(\mathrm{CH}_{3} \mathrm{COO}\right)_{2},+16$ and the reducing valency $(\mathrm{F})$ of citric acid was +18 . The amount of citric acid required was calculated for $\mathrm{LiMg}_{0 \cdot 10}$ $\mathrm{Mn}_{1.90} \mathrm{O}_{4}$ system by using this concept to get

$$
\begin{gathered}
1 \times(-5)+(-10 \times 1 \times 0.10)+(16 \times 1 \times 1.90)+ \\
18 n=0, n=1.35 \mathrm{M} .
\end{gathered}
$$

Therefore, the required amount of citric acid was $1.35 \mathrm{M}$. But the amount of PEG optimized empirically was equivalent to the amount of citric acid taken. The same procedure was followed for other ratios such as $0 \cdot 15,0 \cdot 20$ and $0 \cdot 25$.

The viscous solution so obtained was further heated to $140^{\circ} \mathrm{C}$ for $3 \mathrm{~h}$ for esterification reaction. This precursor was then pyrolysed at $340^{\circ} \mathrm{C}$ for $3 \mathrm{~h}$ in air. In this way cubic spinel $\operatorname{LiMg}_{x} \mathrm{Mn}_{2-x} \mathrm{O}_{4}$ powder was obtained. The resultant products were collected and subjected to both physical characterization and electrochemical studies.

\subsection{Physical characteristics}

$\mathrm{X}$-ray diffraction measurements were made from JEOL (JDX 8030) X-ray diffractometer using nickel filtered $\mathrm{Cu}-\mathrm{K} \alpha$ radiation to identify the crystalline phase of the synthesized materials. The thermal decomposition behaviour of the precursor sample, $\mathrm{LiMg}_{0.20} \mathrm{Mn}_{1 \cdot 80} \mathrm{O}_{4}$, was made using a simultaneous TG/DTA thermal analyser (STA-1500 Model) at the heating rate of $10^{\circ} \mathrm{C} / \mathrm{min}$ under ambient atmosphere. The microstructure of the powder was observed using JEOL (JSM-840 A) scanning electron microscope.

\subsection{Electrochemical characteristics}

$\mathrm{LiMg}_{y} \mathrm{Mn}_{2-y} \mathrm{O}_{4}$ powders were electrochemically characterized by fabricating 2016 coin cells which consisted of lithium anode, $\mathrm{LiMg}_{y} \mathrm{Mn}_{2-y} \mathrm{O}_{4}$ powder cathode, polypropylene separator and a solution of $1 \mathrm{M} \mathrm{Li} \mathrm{PF}_{6}$ in $1: 1(\mathrm{v} / \mathrm{v})$ ratio of $\mathrm{EC}$ and DEC electrolyte. The cathode was made of a mixture containing $\mathrm{LiMg}_{y} \mathrm{Mn}_{2-y} \mathrm{O}_{4}$ powder, acetylene black and polyvinylidene fluoride (PVdF) binder in $\mathrm{N}-$ methyl-2-pyrrolidone (NMP) in the 80:10:10 weight ratio. This mixture was spread over an expanded microgrid and was then pressed at a pressure of $5 \mathrm{tons} / \mathrm{cm}^{2}$ and dried at $120^{\circ} \mathrm{C}$ for $5 \mathrm{~h}$ in an oven. The cells were assembled in an argon filled dry box. The charge and discharge cycling was performed galvanostatically at the current density of $0.2 \mathrm{~mA} / \mathrm{cm}^{2}$ within voltages of $3 \cdot 2-4 \cdot 5 \mathrm{~V}$.

\section{Results and discussion}

The optimum temperature of phase formation and/or crystallization of the $\mathrm{LiMg}_{0 \cdot 20} \mathrm{Mn}_{1 \cdot 80} \mathrm{O}_{4}$ precursor sample is $490 \cdot 17^{\circ} \mathrm{C}$ which is confirmed by thermal analysis as shown in figure 1 . This result displays two discrete weight loss regions occurring at $381 \cdot 5^{\circ} \mathrm{C}$ and $490 \cdot 2^{\circ} \mathrm{C}$. An endothermic peak is observed at about $381.49^{\circ}$ accompanied by a noticeable weight loss of $2.5 \%$. With continuous heating, the mass loss increases, owing to the combustion nature of citric acid together with nitrate precursor complexes and resulting in second exotherm whose onset begins at $490 \cdot 2^{\circ} \mathrm{C}$ with an end at $534.5^{\circ} \mathrm{C}$ accompanied by huge mass loss of $70.4 \%$. This indicates that the compound begins to decompose at lower temperatures and the exothermic combustion of citric acid supplying adequate heat energy for initiating the crystallization of $\mathrm{LiMg}_{y} \mathrm{Mn}_{2-y} \mathrm{O}_{4}$ powder. There are two distinguishable exothermic transformations deduced from the DTA data. The exotherm occurring at $490 \cdot 2^{\circ} \mathrm{C}$ indicates phase formation and/or crystallization of the cubic spinel, $\mathrm{LiMg}_{x} \mathrm{Mn}_{2-x} \mathrm{O}_{4}$.

Figure 2 shows $\mathrm{X}$-ray diffraction patterns of a series of powders with different $x$ in $\mathrm{LiMg}_{y} \mathrm{Mn}_{2-y} \mathrm{O}_{4}$ materials calcined at $550^{\circ} \mathrm{C}$ for $5 \mathrm{~h}$ in air. All these samples were identified as a single phase cubic spinel with a space group, $\overline{F d 3 m}$. The lattice constant values of $\mathrm{LiMg}_{y} \mathrm{Mn}_{2-y} \mathrm{O}_{4}$ samples were presented in table 1. As compared with $\mathrm{LiMn}_{2} \mathrm{O}_{4}$, the lattice parameters of $\mathrm{LiMg}_{y} \mathrm{Mn}_{2-y} \mathrm{O}_{4}$ slightly decreased with increase in substitution of $\mathrm{Mg}^{2+}$ content (Liu et al 1996; Idemoto et al 1999) and hence the Bragg planes (440) and (531) were slightly shifted towards lower $2 \theta$ angle. Figure 3 represents the variation of the cubic lattice parameters of $\mathrm{LiMg}_{y} \mathrm{Mn}_{2-y} \mathrm{O}_{4}$ as a function of the $\mathrm{Mg}$ content. It is obvious that a slight decrease in lattice parameter was observed due to the partial replacement of $\mathrm{Mn}$ by $\mathrm{Mg}^{2+}$. This increases the average $\mathrm{Mn}$

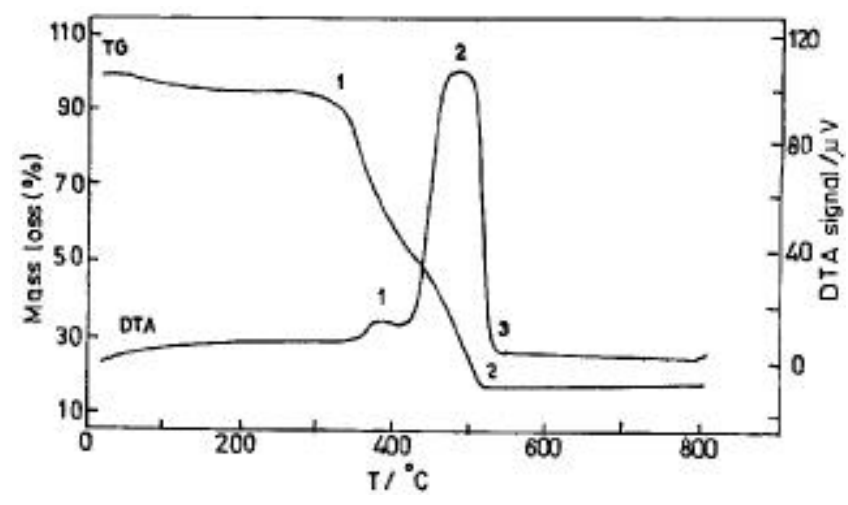

Figure 1. TG and DTA scans of the precursor sample, $\mathrm{LiMg}_{0 \cdot 20} \mathrm{Mn}_{1 \cdot 80} \mathrm{O}_{4}$. 
valency from $\mathrm{Mn}^{3+}$ to $\mathrm{Mn}^{4+}$. Also the $\mathrm{Mg}^{2+}$ replaces $\mathrm{Mn}^{3+}$ in the $16 d$ octahedral site and hence the strong Bragg plane (220) was not observed at $2 \theta=30^{\circ}$, which is extremely sensitive to the occupancy of the 8 a tetrahedral site (Julien et al 2001).

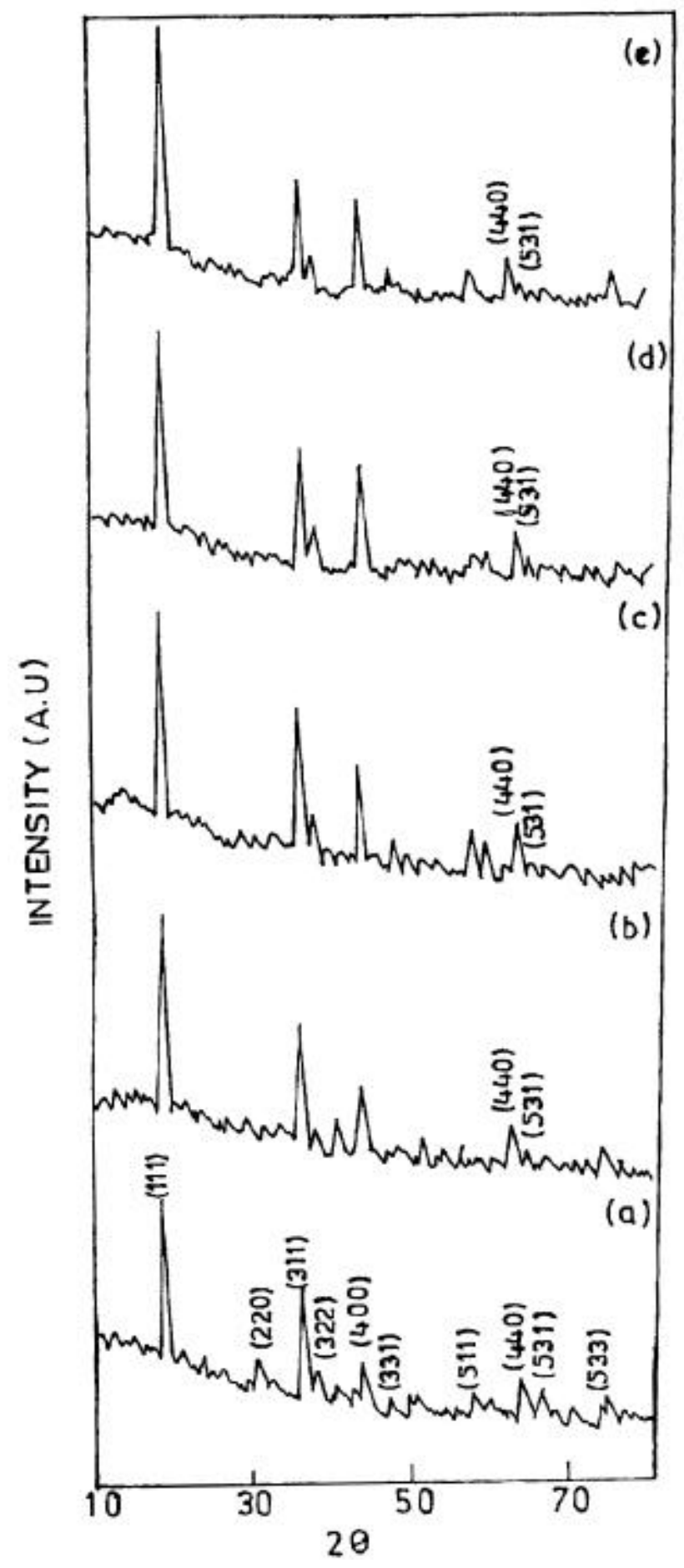

Figure 2. X-ray diffraction patterns for cubic spinel, $\mathrm{LiMg}_{y} \mathrm{Mn}_{2-y} \mathrm{O}_{4}$, where (a) $y=0 \cdot 0$, (b) $y=0 \cdot 05$, (c) $y=0 \cdot 10$, (d) $y=0 \cdot 15$ and (e) $y=0 \cdot 20$ obtained by modified Pechini process.
The $4 \mathrm{~V}$ discharge capacities of the cathodes of various compositions obtained in the first cycle (figure 4) along with the theoretical values are shown in table 2 . The initial discharge capacities of $\mathrm{Li} / \mathrm{LiMn}_{2} \mathrm{O}_{4}(y=0)$ is $137 \mathrm{mAh} / \mathrm{g}$. The initial discharge capacities of $\mathrm{Li} / \mathrm{LiMg}_{y} \mathrm{Mn}_{2-y} \mathrm{O}_{4}$ from $y=0$ to 0.25 are $132 \mathrm{mAh} / \mathrm{g}, 118 \mathrm{mAh} / \mathrm{g}, 100 \mathrm{mAh} / \mathrm{g}$ and $90 \mathrm{mAh} / \mathrm{g}$, respectively. Since deintercalation of $\mathrm{Li}^{+}$from the spinel structure must be electrically compensated by oxidation of $\mathrm{Mn}^{3+}$ to $\mathrm{Mn}^{4+}$. This suggests that even for substituted spinel phases, only the amount of $\mathrm{Mn}^{3+}$ contributes to the discharge capacity. So the initial capacity of $\mathrm{LiMg}_{y} \mathrm{Mn}_{2-y} \mathrm{O}_{4}(0 \leq y \leq 0 \cdot 25)$ is limited by the initial amount of $\mathrm{Mn}^{3+}$ in the $16 d$ sites. The discharge capacity versus cycle number of $\mathrm{Li} / \mathrm{LiMg}_{y} \mathrm{Mn}_{2-y} \mathrm{O}_{4}$ with $y=0$ to $0 \cdot 25$ is shown in figure 5 . The capacity loss observed for undoped $\mathrm{LiMn}_{2} \mathrm{O}_{4}$ is about $25 \%$ after 25 cycles, whereas that for $\mathrm{Li} / \mathrm{LiMg}_{y} \mathrm{Mn}_{2-y} \mathrm{O}_{4}$ from $y=0.05$ to 0.25 are $12 \%$, $2.33 \%, 7 \%$ and $9.5 \%$, respectively. This can be achieved by the substitution of $\mathrm{Mg}^{2+}$ into the $\mathrm{Mn}$ site accompanied

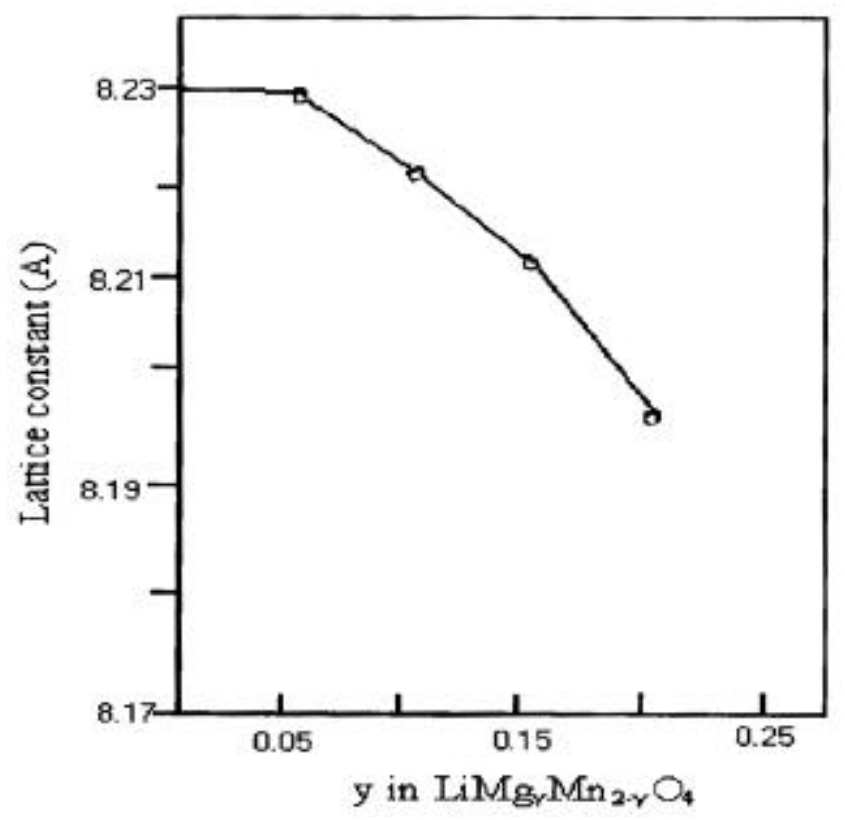

Figure 3. Variation of lattice constant of $\operatorname{LiMg}_{y} \mathrm{Mn}_{2-y} \mathrm{O}_{4}$ as a function of $\mathrm{Mg}$ content.

Table 1. Comparison between the standard and experimentally observed lattice constant values of cubic spinel, $\mathrm{LiMg}_{y} \mathrm{Mn}_{2-y} \mathrm{O}_{4}$.

\begin{tabular}{lcc}
\hline Compound & $\begin{array}{c}\text { Standard lattice } \\
\text { constant value }(\AA)\end{array}$ & $\begin{array}{c}\text { Experimentally } \\
\text { observed lattice } \\
\text { constant value }(\AA)\end{array}$ \\
\hline $\mathrm{LiMn}_{2} \mathrm{O}_{4}$ & $8 \cdot 2358$ & $8 \cdot 2293$ \\
$\mathrm{LiMg}_{0.05} \mathrm{Mn}_{1.95} \mathrm{O}_{4}$ & 8.2356 & $8 \cdot 2287$ \\
$\mathrm{LiMg}_{0.1} \mathrm{Mn}_{1.9} \mathrm{O}_{4}$ & $8 \cdot 2338$ & $8 \cdot 2205$ \\
$\mathrm{LiMg}_{0.15} \mathrm{Mn}_{1.85} \mathrm{O}_{4}$ & 8.2191 & $8 \cdot 2123$ \\
$\mathrm{LiMg}_{0.2} \mathrm{Mn}_{1.8} \mathrm{O}_{4}$ & 8.2154 & $8 \cdot 1976$ \\
\hline
\end{tabular}


Table 2. $4 \mathrm{~V}$ capacities of various compositions (mAh/g).

\begin{tabular}{lcc}
\hline Formula & Practical capacity & Theoretical capacity \\
\hline $\mathrm{LiMn}_{2} \mathrm{O}_{4}[\mathrm{Li}]_{8 \mathrm{a}}\left[\mathrm{Mn}^{3+} \mathrm{Mn}^{4+}\right]_{16 \mathrm{~d}}\left[\mathrm{O}_{4}\right]_{32 \mathrm{e}}$ & 137 & $148 \cdot 2$ \\
$\mathrm{LiMg}_{0.05} \mathrm{Mn}_{1.95} \mathrm{O}_{4}[\mathrm{Li}]_{8 \mathrm{a}}\left[\mathrm{Mg}^{2+}{ }_{0.05} \mathrm{Mn}^{3+}{ }_{0.9} \mathrm{Mn}^{4+}{ }_{1 \cdot 05}\right]_{16 \mathrm{~d}}\left[\mathrm{O}_{4}\right]_{32 \mathrm{e}}$ & 132 & $134 \cdot 5$ \\
$\mathrm{LiMg}_{0.1} \mathrm{Mn}_{1.9} \mathrm{O}_{4}[\mathrm{Li}]_{8 \mathrm{a}}\left[\mathrm{Mg}^{2+}{ }_{0.10} \mathrm{Mn}^{3+}{ }_{0.8} \mathrm{Mn}^{4+}{ }_{1 \cdot 10}\right]_{16 \mathrm{~d}}\left[\mathrm{O}_{4}\right]_{32 \mathrm{e}}$ & 118 & $120 \cdot 61$ \\
$\mathrm{LiMg}_{0.15} \mathrm{Mn}_{1 \cdot 85} \mathrm{O}_{4}[\mathrm{Li}]_{8 \mathrm{a}}\left[\mathrm{Mg}^{2+}{ }_{0.15} \mathrm{Mn}^{3+}{ }_{0.7} \mathrm{Mn}^{4+}{ }_{1 \cdot 15}\right]_{16 \mathrm{~d}}\left[\mathrm{O}_{4}\right]_{32 \mathrm{e}}$ & 100 & $106 \cdot 45$ \\
$\mathrm{LiMg}_{0.2} \mathrm{Mn}_{1 \cdot 8} \mathrm{O}_{4}[\mathrm{Li}]_{8 \mathrm{a}}\left[\mathrm{Mg}^{2+}{ }_{0 \cdot 20} \mathrm{Mn}^{3+}{ }_{0.6} \mathrm{Mn}^{+4}{ }_{1.20}\right]_{16 \mathrm{~d}}\left[\mathrm{O}_{4}\right]_{32 \mathrm{e}}$ & 90 & $92 \cdot 046$ \\
\hline
\end{tabular}

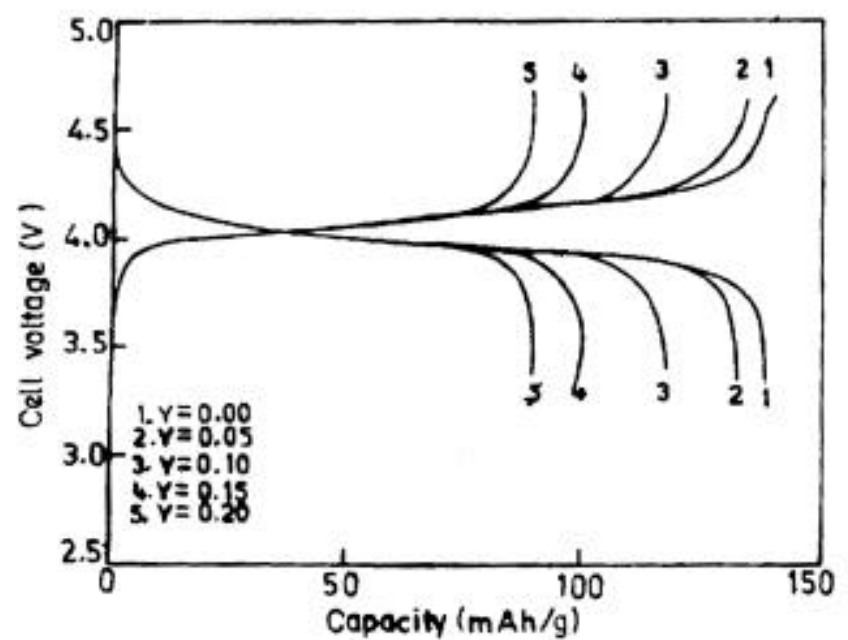

Figure 4. Electrochemical features of $\mathrm{Li} / \mathrm{LiMg}_{y} \mathrm{Mn}_{2-y} \mathrm{O}_{4}$ cells with $y=0 \cdot 0,0 \cdot 05,0 \cdot 10,0 \cdot 15,0.20$ during first chargedischarge cycle in the voltage range of 3.2 and $4.5 \mathrm{~V}$ at a current density of $0.2 \mathrm{~mA} / \mathrm{cm}^{2}$.

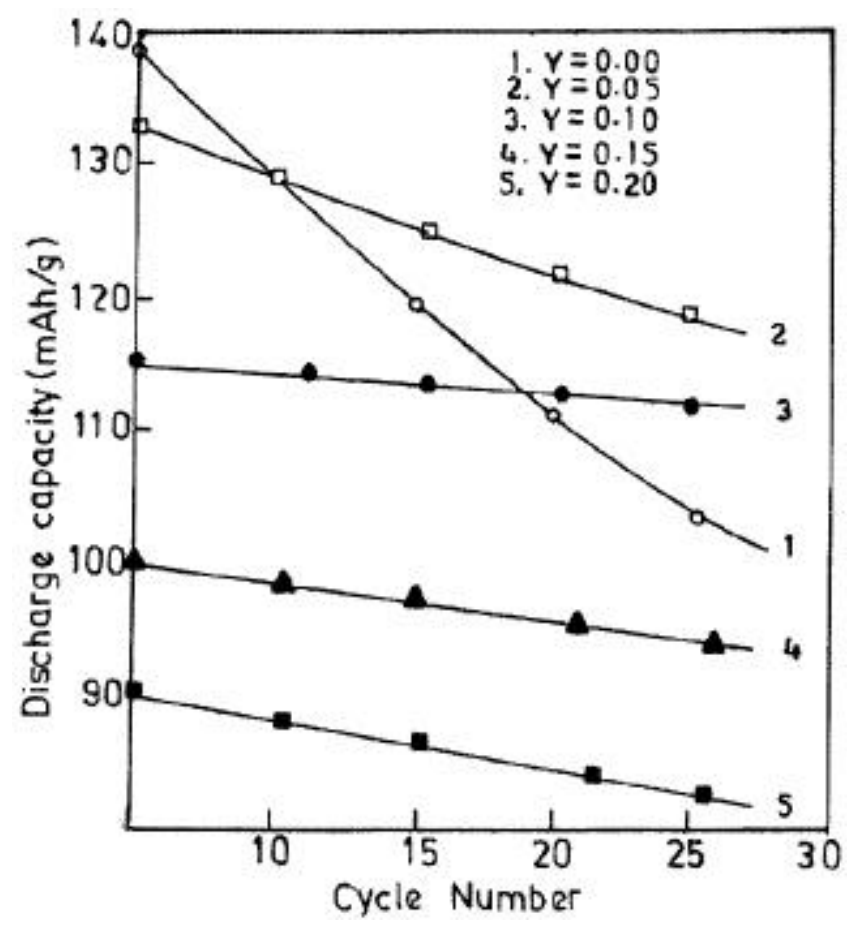

Figure 5. Relationship between the discharge capacity and cycle number of $\mathrm{Li} / \mathrm{LiMg}_{y} \mathrm{Mn}_{2-y} \mathrm{O}_{4}$ cells in the voltage range of $3 \cdot 2-4 \cdot 5 \mathrm{~V}$ at a current density of $0.2 \mathrm{~mA} / \mathrm{cm}^{2}$.

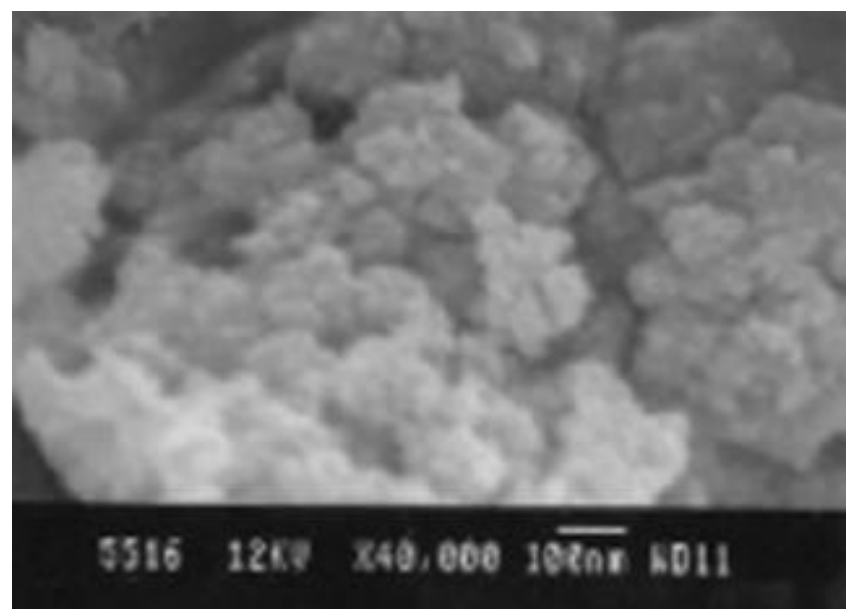

Figure 6. Scanning electron micrograph of the cubic spinel, LiMg ${ }_{0.10} \mathrm{Mn}_{1.90} \mathrm{O}_{4}$, obtained by modified Pechini process.

by the oxidation of $\mathrm{Mn}^{3+}$ into $\mathrm{Mn}^{4+}$ resulting in an increase in the average valency of Mn which suppresses the John-Teller distortion. Li et al (1996) also reported that the doped materials enhance the stability of the octahedral sites in the spinel skeleton structure. Hence, the electrochemical stability of $\mathrm{LiMn}_{2} \mathrm{O}_{4}$ is less than that of the $\mathrm{Mg}$ substituted $\mathrm{LiMn}_{2} \mathrm{O}_{4}$. These results were in good agreement with the reported results (Jeong et al 2001). Among the various compositions, $\mathrm{LiMg}_{0 \cdot 10} \mathrm{Mn}_{1 \cdot 90} \mathrm{O}_{4}$ shows better reversibility, because the suppression of JohnTeller distortion is high in 0.10 substitution than 0.05 substitution. Moreover, electrochemical inactive $\mathrm{Mn}^{4+}$ species is low in $0 \cdot 10$ substitution than in $0 \cdot 15,0.20$ and $0 \cdot 25$ substitutions. Figure 6 shows the scanning electron microscope $(\mathrm{SEM})$ pattern of $\mathrm{LiMg}_{0 \cdot 10} \mathrm{Mn}_{1 \cdot 90} \mathrm{O}_{4}$ powder calcined at $550^{\circ} \mathrm{C}$ for $5 \mathrm{~h}$ in air. The photograph confirms the formation of spherical grains of sub-micron nature of lithium magnesium manganate with an average size of $<50 \mathrm{~nm}$ accompanied by controlled grain growth.

\section{Conclusions}

The following conclusions were drawn from the present study:

(I) The modified Pechini process is found to be an easy method for the synthesis of cubic spinel, $\mathrm{LiMg}_{y} \mathrm{Mn}_{2-y} \mathrm{O}_{4}$ powders, at moderate temperature. 
(II) X-ray diffraction analysis confirms the phase purity and the structure of the synthesized products.

(III) Thermal analysis indicates the exact phase formation and/or crystallization temperature of the $\mathrm{LiMg}_{0.20} \mathrm{Mn}_{1 \cdot 80} \mathrm{O}_{4}$ sample. It is found that the product undergoes complete crystallization at $535^{\circ} \mathrm{C}$.

(IV) The SEM analysis confirms the formation of spherical grains of $<50 \mathrm{~nm}$ accompanied by controlled grain growth of the powder.

(V) The charge-discharge behaviour of the synthesized $\mathrm{LiMg}_{0 \cdot 10} \mathrm{Mn}_{1.90} \mathrm{O}_{4}$ sample shows the initial discharge capacity of $118 \mathrm{mAh} / \mathrm{g}$ and its capacity loss at even 25th cycle is only $2 \cdot 33 \%$.

Thus the modified Pechini process used in this investigation is found to be a very useful process for synthesizing $\mathrm{Mg}$-doped $\mathrm{LiMn}_{2} \mathrm{O}_{4}$ spinel at moderate temperature which has good cyclability. Hence, the compound could be used as an effective cathode material for high voltage rechargeable lithium batteries.

\section{Acknowledgements}

The authors gratefully acknowledge DST, New Delhi, for financial support.

\section{References}

Bach S, Henry M, Baffier N and Livaje J 1990 J. Solid State Chem. 88325
Barboux P, Tarascon J M and Shokoohi F K 1991 J. Solid State Chem. 94185

Gummow R J, Dekock A and Thackeray M M 1994 Solid State Ionics 6959

Guyomard D and Tarason J M 1994 Solid State Ionics 69222

Hwang B J, Santhanam R and Liu D G 2001 J. Power Sources 10186

Idemoto Y, Koura N and Udagawa Y 1999 J. Electrochem. Soc. Jap. 67235

Jain S R, Adiga K C and Pai V R 1981 Comb. Flame 4071

Jeong I S, Kim J and Gu H B 2001 J. Power Sources 10255

Julien C, Ziolkiewicz S, Lemal M and Massot M 2001 J. Mater. Chem. 111837

Kovacheva D, Hristo, Petrov K and Sankar M 2002 J. Mater. Chem. 121184

Lee $\mathrm{J}$ H, Jin K, Hong J K, Jang D H, Sun Y-K and Seung M O 2004 J. Power Sources 897

Li G, Ikuta H, Uchida M and Wakihara M 1996 J. Electrochem. Soc. 143178

Liu D G, Farrington G C, Chaput F and Dunn B 1996 J. Electrochem. Soc. 143876,3590

Morita M, Nakagawa T, Yamada O, Yoshimoto $\mathrm{N}$ and Ishikawa M 2001 J. Power Sources 97354

Myung S T, Chung H T, Komaba S, Kumagai N and Gu H B 2000 J. Power Sources 90103

Ozhuku T, Kitagawa M and Hirai T 1990 J. Electrochem. Soc. 137760

Shaju K M, Subba Rao G V and Chowdari B V R 2002 J. Electrochim. Acta 48145

U.S. Pat. 1967 3,330,697

Yamada A 1996 J. Solid State Chem. 122160 